\title{
Bombongan: Expressive Speech Act Ethnic Java of Panaragan in the Art of Reyog
} (An Ethnopragmatic Study)

\author{
Alip Sugianto \\ Universitas Muhammadiyah Ponorogo \\ Ponorogo, Indonesia \\ sugiantoalip@gmail.com
}

\author{
Wakit Abdullah \\ Universitas Sebelas Maret \\ Surakarta, Indonesia \\ abdullahwakit@yahoo.com
}

\begin{abstract}
Ethnic Java of Panaragan is an ethnic group in Ponorogo society. In Ponorogo society has a customary figure named warok, in the art of reyog, warok as the leader of the reyog community. As an art that requires courage, many warok use expressions speech act to express a flattery as an appreciation of courage to generate motivation. It is very interesting to be studied through the approach of Pragmatic science by specializing the theory of expressive speech acts Searle to know the purpose of speech based on the context of the speech situation so that it can be understood as a form of wealth of wisdom in the arts reyog Ponorogo.
\end{abstract}

Keywords-bombongan; speech act; expressive

\section{INTRODUCTION}

Ethnic Java Panaragan is one of the sub-regions of culture in East Java which has a diversity of tradition art that is deeply rooted in society. The Panaragan ethnic community inhabits a region on the western slopes of Mount Wilis exactly in Ponorogo District. Since ancient times, the ethnic community of Panaragan is known as a brave who flows the blood heroes of the warok like warok Singo bowo, warok Gunoseco, warok Suromenggolo and so on which from transformation from generation to generation until now.

The system of transformations, deeply rooted through various customs and culture of society as a medium of unifying ethnicity through Ponorogo reyog art field, in the process can not be denied in translating a cultural transfer firmly attached to the language. This is in line with the opinions of Abdul Chaer and Leoni Agustin citing Silzer (1995, p. 218) that language and cultural relations are conjoined twins, two closely bound phenomena, such as one-sided relationship with the other side of the coin, one side is language, and the other is culture.

Relationships are mutually influence each other, one of the cultural influences in the use of language is reflected in the bombongan expression in the group of Ponorogo reyog art. Bombongan can be interpreted as a form of speech acts flattering, praising and motivating to have a high confidence and confidence as a brave heir to the blood of warok Ponorogo or in the form of an expression nek wani wedi wedi-wedi, nek wedi aja wani-wani. The phrase has the intention that if dare never fear, if afraid, do not be brave.
Speech act bombongan in this group of reyog art has a uniqueness, that is though impressed rough but has good intentions. It is like the opinion of warok Purwowidjoyo who said that the language Panaragan has the following describtion:

"Akeh akehe wong Ponorogo omonge kaku, srogalsrogol, kandha apa anane, ora duwe pariasi kandha lelamisan. Tata lahire kasar, nanging satemen atine mulus lan alus" (Alip Sugianto, et al, 2017, p. 603).

Based on the above opinion can be understood the essence how to speak of Ponorogo people seem stiff, srogal-srogol and truth, which has no variation of stale voice that sounds like rough, but in essence his heart smooth and smooth. One form of language expression contained in the Javanese ethnic community of Panaragan is the bombongan languages which are often used by the Reyog community in particular with certain objectives which are expected to have an implication in accordance with the situation and conditions that occur in generating psychological psychology of konco reyog.

Speech act of bombongan in the group is very interesting to be studied from various perspective of linguistics. One of them is Pragmatic science as one of study which studying language with context which is often called speaker's meaning or interpretation of speaker. The Pragmatic study in the language of this group, according to the scope of the author has never been reviewed by other researchers, so this study is still original with the hope of producing a new discovery, especially the uniqueness and peculiarities of Panaragan language in Pragmatic science.

\section{LITERATURE REVIEW}

A. Speech Act

Searle (1969) classified speech acts into five types that included (1) asserting that is the form of speech that binds the speaker to the truth of the proposition which is expressed e.g. stating, suggesting, boasting, complaining and claiming, (2) directive that is the form of speech intended by the speaker to make an effect for the partner to take action such as ordering, commanding, requesting, advising and recommending, (3) expressive is a form of speech that serves to express or show the psychological attitude of the speaker to something circumstances, such as thanking, congratulation, pardoning, blaming, praising and 
condolencing. (4) commissive form of speech that serves to declare a promise or offer such as promising, vowing and offering something (5) declarative. the form of speech that connects the content of the utterance to the reality of resigning, dismissing, christening giving names, appointing and excommunicating and punishing. Base on the five types of speech acts above, then in the study of speech acts in this study specialize in expressive speech acts contained in the language of the group reyog community conducted by the warok Ponorogo with a specific goal to build a culture that is in harmony with the identity of reyog art .

\section{B. Context in Pragmatic}

Context in pragmatic science has a very important role. These two relationships are so closely linked that they can not be separated from each other like spicy dishes. We will not know the taste of a dish without the flavor of taste, otherwise the spice function will not taste delicious without any cuisine. So it can be understood that pragmatic science is closely related to the context. The relationship of both according to the expert can be explained as follows.

Pragmatics is the study of the relations between language and context that are basic to an account of language understanding. (Levinson, 1983, p. 21).

From the definition above can be understood that Pragmatic is a study of the relationship between language and context as the basis of consideration to understand the language. Or in other words to understand the full meaning, the context in pragmatics has an important role to know something in comprehension. Without involving the context it cannot be said to be a Pragmatic study, but rather into structural language studies such as morphology, syntax and so on.

\section{METHOD}

This research includes qualitative descriptive by using speech or sentence in expressive speech acts of Javanese Ethnic of Panaragan community found in Ponorogo reyog art. Sources of data, whether there is in the speech or sentence contained in ethnic t-shirts which then performed data collection by listening and recorded and then analyzed to be presented into a description in pragmatic.

\section{RESUlT AND DISCUSSION}

The language of bombongan which reflected in Ponorogo reyog art expressions is a language used to flatter or praise the reyog players in order to create an effect of self-confidence and courage that indirectly creates an atmosphere and builds a culture of society because it is created from frequently used languages. The language then becomes a motivational supplement that will someday be imprinted in the mindset of the people of Ponorogo which has an effect on the main audience of the generation of warok must appear brave and confident. This expressive form of speech acts, among others, in the following expression.
"Ikilo dlondonge wong Ponorogo"

The above sentence is commonly expressed by the elders in the art of reyog to the players. In that sentence there is the use of word dlondonge meaning is grandchild of warok. The word, as a form of expressive expression that as a grandson warok Ponorogo must be a brave, the utterance as an effort to motivate when appearing in reyog performances, especially in the contraction must dare not to be embarrassed as a warok grandchild. In addition there is usually also a speech as follows.

\section{"Jian ora dlomok"}

The intent of speech act above is expressing a compliment to the warok's grandchild for the success of reyog art performance that is able to bring admiration or amazement when performing in a stunning attraction to the audience so that many people who see feel entertained on the display of reyog art displayed. The admiration is expressed through the use of the word dlomok which has a general meaning, ora dlomok has a similiar word in Javanese ora lumrah or something that is not common or commonly done as can be done by the public at large on the attractions of reyog art.

As for the act of speech expression to motivate to be courageous in doing something then it is revealed in the form of following speech acts.

\section{"Jadog po ra"}

The meaning of the word above has the meaning of the word jadog with a daring word. Jadog po ra as a brave or not expression. The phrase as a form of triggers and promoters andrenalin courage the warok generation in doing something that according to warok someone has the ability but have not dared to do. When successful or completed and successful then warok praised the appearance of attraction and appearance of the reyog community with the following expression.

$$
\text { "Jegeg lur" }
$$

The word Jegeg has a great meaning, while the expression of jungle is a familiar call of dulur or brother to the reyog players. This is to show a strong sense of solidarity and kinship among members of the reyog community. Then the form of appreciation is expressed by speech act jegeg expression. Jegeg's phrase then became popular after the Regent Ponorogo Amin era in every opportunity always praised the people of Ponorogo with the phrase Ponorogo jegeg, which then by some people made slogans in Panaragan ethnic shirts in the hope continue to be a great person through the realm of the game of words.

Beside that, of course in a success or greatness in something, especially in playing the game of reyog art can not be separated from the routine exercise in the body. The exercise process can train both body motion and excellent strength in the stage. Conversely, if you never practice or maintain the ability possessed it will be seen in a rigid movement pattern. The process of rehearsal art training becomes a serious part that must be passed. When the process of training regularly it will get motivated with the expression of the word.

"Sapa sing gitapan, bakale mapan" 
The meaning of the speech above is who is diligent, it will be established or successful or in the Arabic language mahfudzot known as man jadda wa jadda, who is truly then he can. So in the process of training in reyog art required a seriousness it will become an artist who succeeds in preserving the arts noble. Praise of ordinary gestures is intended for people who are diligent in doing things to be more energized and people who get praise of the letters will feel happy.

The result of the training process is also actualized in everyday life will be a strong and agile person. So that will get flattery to a reyog community will be famous for the following expression.

"Cukat tandang bocah kuwi"

This means that it is really nimble or ready to respond because in the arts reyog require alertness as a representation of the image of troops who will fight as a drama or story played based on a particular story line according to the version or guidelines in the art of reyog. Cukat away can be categorized as a form of praise because it is tied to the context of the situation in the practice of implementation in reyog art.

Ponorogo reyog art, also has the function as a strong fraternal adhesive, as the association that at all times of exercise as well as exercise so that this art is also as a very effective media in keeping unity and unity of the nation through the existing culture. Such a culture is also expressed by the following expression.

"Ayo latihan reyog ben regeng gayeng, ben ora crah agawe bubrah"

The purpose of expressive speech is to invite to reyog exercises with hanging together will make the relationship brotherly so tightly, let be not fragments that can cause damage. So with a casual gayeng as a means to minimize quarrels, or disputes but with regeng gayeng make something valuable with a sense of brotherhood is often illustrated also with the expression ara ana kemulyan tanpo paseduluran.

\section{V.CONCLUSION}

Based on the above discussion, it can be concluded that the expressive speech acts Javanese society of Panaragan there are uniqueness and special of the language used as revealed in the choice of words dlondonge, jegeg, dlomok, cukat tandang and others as an effort to appreciate the players in the art of reyog in order to have a sense courage and confidence as a grandson of warok Ponorogo with praise or flattery so do something well. Similarly, a brief article about the language of this Javanese ethnic group, there is a lack of apology for perfection only belongs to God and there are input authors can gladly contact on emails listed above.

\section{References}

Alip Sugianto, et al. (2017). Sapir Whorf hyphotesis and its relevane to the language ekspression "bombongan" in ethnic Java Panaragan. International Conference on Islamic Eduation. Ponorogo 4 November 2017.
Abdul Chaer dan Leoni Agustin. (1996). Sosiolinguistik sebuah pengantar awal. Jakarta: Rineka Cipta.

Searle, John, R. (1969). Speech at an comprehensive grammar of the english language. Cambridge: Cambridge University Press.

Levinson, Stephen C. (1983). Pragmatics. Londong: Longman. 